\title{
Receptor-mediated Endocytosis of Albumin by Kidney Proximal Tubule Cells Is Regulated by Phosphatidylinositide 3-Kinase
}

\author{
Nigel J. Brunskill, ${ }^{\star \ddagger}$ Jamie Stuart, ${ }^{\star}$ Andrew B. Tobin, ${ }^{\star}$ John Walls, ${ }^{\ddagger}$ and Stefan Nahorski ${ }^{\star}$ \\ $*$ Department of Cell Physiology and Pharmacology, and ${ }^{\ddagger}$ Department of Nephrology, Leicester University Medical School, Leicester LE1 \\ $9 H N$, United Kingdom
}

\begin{abstract}
Receptor-mediated endocytosis of albumin is an important function of the kidney proximal tubule epithelium. We have measured endocytosis of $\left[{ }^{125} \mathrm{I}\right]$-albumin in opossum kidney cells and examined the regulation of this process by phosphatidylinositide 3-kinase (PI 3-kinase). Albumin endocytosis was inhibited by both wortmannin $\left(\mathrm{IC}_{50} 6.9 \mathrm{nM}\right)$ and LY294002 $\left(\mathrm{IC}_{50} 6.5 \mu \mathrm{M}\right)$ at concentrations that suggested the involvement of PI 3-kinase in its regulation. Recycling rates were unaffected. We transfected $\mathrm{OK}$ cells with either a wild-type p85 subunit of PI 3-kinase, or a dominant negative form of the $\mathrm{p} 85$ subunit $(\Delta \mathrm{p} 85)$ using the LacSwitch expression system. Transfects were screened by immunoblotting with anti-PI 3-kinase antibodies. Under basal conditions, transfects demonstrated no expression of p85 or $\Delta \mathrm{p} 85$, but expression was briskly induced by treatment of the cells with IPTG $\left(\mathrm{EC}_{50} 13.7 \mu \mathrm{M}\right)$. Inhibition of PI 3-kinase activity by $\Delta \mathrm{p} 85$ was confirmed by in vitro kinase assay of anti-phosphotyrosine immunoprecipitates from transfected cells stimulated with insulin. Expression of $\Delta$ p85 resulted in marked inhibition of albumin endocytosis, predominantly as a result of reduction of the $V_{\text {max }}$ of the transport process. Expression of p85 had no significant effect on albumin uptake. The results demonstrate that PI 3-kinase regulates an early step in the receptor-mediated endocytosis of albumin by kidney proximal tubular cells. (J. Clin. Invest. 1998. 101: 2140-2150.) Key words: proximal tubule • PI 3-kinase • endocytosis • albumin $\bullet$ renal failure
\end{abstract}

\section{Introduction}

The glomerular filtration barrier provides an effective mechanism for preventing the passage of excess protein from the plasma to the urine. Despite the efficiency of this barrier, micropuncture studies in rats have shown that protein, particularly albumin, is present in appreciable quantities in the glomerular filtrate. The measured concentrations of albumin in this location range from 10-135 mg/liter (1-4). Extrapolating these observations to man, assuming a glomerular filtration

Address correspondence to Nigel J. Brunskill, Department of Cell Physiology and Pharmacology, Faculty of Medicine, Medical Sciences Building, University Road, Leicester LE1 9HN, United Kingdom. Phone: 0116-252-3078. FAX: 0116-252-5045. E-mail: njb18@le.ac.uk

Received for publication 2 October 1997 and accepted in revised form 6 March 1998.

J. Clin. Invest.

(C) The American Society for Clinical Investigation, Inc. 0021-9738/98/05/2140/11 \$2.00

Volume 101, Number 10, May 1998, 2140-2150

http://www.jci.org rate of $100 \mathrm{ml} / \mathrm{min}$, and an albumin concentration in the glomerular filtrate of $50 \mathrm{mg} / \mathrm{liter}, \sim 7 \mathrm{~g}$ of albumin must cross the glomerular filtration barrier in $24 \mathrm{~h}$ and enter the proximal tubule. However, the urinary excretion of albumin is $<150 \mathrm{mg} /$ $24 \mathrm{~h}$ in health, indicating that albumin is reabsorbed from the tubular fluid. In large part, this reabsorption occurs in the proximal tubule by the proximal tubular epithelium (5).

Albumin reabsorption in the proximal nephron occurs by receptor-mediated endocytosis $(\mathrm{RME})^{1}(6-9)$. The endocytic functions of these cells are of considerable physiological and pathophysiolgical importance, as, in health albumin, reabsorption prevents the loss of large quantities of this important plasma protein in the urine. Whereas, in glomerular diseases, the endocytosis of pathological quantities of filtered protein may exert a toxic and mitogenic effect on the tubular epithelium $(10,11)$. We have previously demonstrated that albumin binds to glycoprotein receptors in the apical membrane of proximal tubule-derived opossum kidney (OK) cells (12), and that subsequent endocytosis of albumin by these cells is regulated by the heterotrimeric GTP-binding protein $\mathrm{G}_{\mathrm{i} \alpha-3}(9)$. However, much remains to be learned about the regulation of protein endocytosis by the proximal tubular epithelium, and how mitogenic effects of albumin may be mediated.

Considerable recent attention has been given to the potential for regulation of endocytosis and other vesicular-trafficking events by the family of phosphoinositide (PI) 3-kinases, that catalyse the phosphorylation of the $3^{\prime}$ position of the inositol ring of phosphoinositides (13-15). Mammalian cells contain at least three classes of PI 3-kinase activity. One of these is highly homologous to the yeast Vps34p protein. In yeast $\mathrm{Vps} 34 \mathrm{p}$ has an essential regulatory role in vacuolar protein targeting and is a phosphatidylinositol (PtdIns) specific 3-kinase (16). The mammalian counterpart of Vps34p is also PtdIns specific and has been ascribed a putative role in the regulation of lysosomal trafficking, although direct evidence is lacking $(17,18)$. A second class of PI 3-kinase activity is regulated by G-protein subunits and has broad specificity for PtdIns, PtdIns (4)-phosphate (PtdIns[4]-P), and PtdIns [4,5]-bisphosphate (PtdIns $\left.[4,5]-\mathrm{P}_{2}\right)(19,20)$. The function of this enzyme activity is unknown.

The prototypic PI 3-kinase is a heterodimer composed of a regulatory p85 and a catalytic p110 subunit $(21,22)$. This enzyme is able to phosphorylate PtdIns, PtdIns(4)-P, and PtdIns(4,5)- $\mathrm{P}_{2}$. Initial work with this enzyme established that it is activated by membrane-bound receptor tyrosine kinases that recruit p85/p110 heterodimers to membrane-bound signaling complexes via SH2 domains of p85 $(21,22)$. This work has progressed such that there now is a clearly demonstrated

1. Abbreviations used in this paper: ECL, enhanced chemiluminescence; IPTG, isopropyl $\beta$-D-thiogalactopyranoside; OK, opossum kidney; P, phosphate; PI, phosphoinositide; PtdIns, phosphatidylinositol; RME, receptor-mediated endocytosis. 
and critical role for heterodimeric PI 3-kinase in receptormediated mitogenesis (23-27).

Currently, however, a number of additional roles for the p85/p110 PI 3-kinase are the subject of scientific attention, and, in particular, a number of authors have implicated this enzyme in the regulation of both secretory and endocytic vesicular formation and transport (13-15). Best studied is insulin signaling, where overexpression of p110 catalytic subunits and dominant negative mutant forms of $\mathrm{p} 85$ has established that insulin-stimulated glucose transport is mediated by this PI 3-kinase via modulation of glucose transporter translocation from an intracellular location to the plasma membrane (28-29).

Two reagents have been useful in the study of PI 3-kinase activity in cells. The use of PI 3-kinase inhibitors, wortmannin, and LY294002, has implicated PI 3-kinase activity in the completion of actin-dependent endocytosis (30), the regulation of fluid phase endocytosis (31), and the fusion of early endosomes (32). Unfortunately, the interpretation of results using wortmannin in particular is complicated by the observations that this agent also potently inhibits other enzymes, PtdIns 4-kinase (33), DNA-dependent protein kinase (34), and phospholipase $A_{2}$ (35). Furthermore, inhibition of PI 3-kinase activity by these agents does not allow precise identification of the particular enzyme responsible for the observed effect.

In view of our interest in the mechanism of RME of albumin by kidney tubule epithelial cells, and the potentially mitogenic effects of albumin on these cells, we examined the possibility that the p85/p110 PI 3-kinase may be involved in this process. We used the established OK cell line as a model of the proximal tubular epithelium, and determined whether the PI 3-kinase inhibitors, wortmannin and LY294002, affected the $\mathrm{RME}$ of albumin. In addition, we measured albumin RME in OK cells transfected with a wild-type p85 or a dominant negative mutant form of p85 $(\Delta \mathrm{p} 85)$ using an inducible expression system to eliminate confounding effects on cell growth. Our results confirm a role for the p85/p110 PI 3-kinase in the regulation of albumin RME in the kidney proximal tubular epithelium, and suggest a possible link between tubular reabsorption of filtered albumin and mitogenic pathways.

\section{Methods}

Reagents and materials. OK cells were obtained from J. Caverzasio (Cantonal Hospital, Geneva, Switzerland) and were used between passages 65-80. Geneticin (G-418) was from GIBCO Life Technologies (Paisley, UK). Hygromycin and wortmannin were from Calbiochem (Nottingham, UK). LY294002 was obtained from Affiniti Research Products (Exeter, UK). Both wortmannin and LY294002 were stored at $-20^{\circ} \mathrm{C}$ as concentrated stocks dissolved in DMSO. To minimize degradation, an aliquot of this stock was thawed and diluted for use immediately before each experiment, and the remainder was discarded. Anti-p85 and PY20 anti-phosphotyrosine antisera were obtained from Transduction Laboratories (Lexington, KY). The cDNAs encoding bovine $\mathrm{p} 85$ and $\Delta \mathrm{p} 85$ were kindly provided by M.D. Waterfield (Ludwig Institute for Cancer Research, London, UK) in the vectors pBS(I)SK and pcDL-SR $\alpha 296$, respectively. Restriction endonucleases were obtained from Pharmacia Biotech (St. Albans, UK), and the LacSwitch Inducible Mammalian Expression System, together with anti-Lac repressor protein antisera were obtained from Stratagene (Cambridge, UK). Primers for polymerase chain reaction were synthesized by GIBCO Life Technologies. ${ }^{125}$ I-labeled human albu$\min (2.5 \mu \mathrm{Ci} / \mathrm{mg})$ was from Amersham (Little Chalfont, UK). Isopropyl $\beta$-D-thiogalactopyranoside (IPTG) and inositol phospholipids were obtained from Sigma (Poole, UK).
Cell culture. OK cells were maintained in DME-Ham's F12 mix (DME-F12) supplemented with $10 \%$ FCS, L-glutamine 2 mmol/liter, $100 \mathrm{U} / \mathrm{ml}$ penicillin, and $0.1 \mathrm{mg} / \mathrm{ml}$ streptomycin. Culture media was changed three times per week. Cells were incubated at $37^{\circ} \mathrm{C}$ in an humidified atmosphere of $5 \% \mathrm{CO}_{2} / 95 \%$ air, and split at confluence approximately once per week. For albumin uptake experiments OK cells were grown in six-well culture dishes and used at confluence, typically $7-10 \mathrm{~d}$ after seeding.

Albumin uptake experiments. Uptake of albumin into OK cells was measured using ${ }^{125} \mathrm{I}$-albumin essentially, as previously described (9). Confluent wild-type, p85, or $\Delta$ p85-transfected OK cells in six-well plates were quiesced in serum-free DME-F12 for $2 \mathrm{~h}$ before initiation of ${ }^{125} \mathrm{I}$-albumin uptake. All uptake experiments were performed with ${ }^{125} \mathrm{I}$-albumin in serum-free DME-F12 at $37^{\circ} \mathrm{C}$. Various concentrations of ${ }^{125} \mathrm{I}$-albumin were incubated with the cells at $37^{\circ} \mathrm{C}$ for $15 \mathrm{~min}$. At the end of this period the uptake was terminated by rapid removal of the uptake solution followed by washing with three 2-ml aliquots of ice-cold PBS, pH 7.4 per well of the six-well plate. The PBS was removed and cell monolayers were then lysed by addition of $1 \mathrm{M}$ $\mathrm{NaOH}$ to each well. An aliquot of this lysate was taken for protein estimation, and the amount of ${ }^{125} \mathrm{I}$-albumin bound and taken up by the cells was determined by counting the remainder of the cell extract in a gamma counter. In other experiments, the time course of albumin uptake was measured by incubating OK cells with $150 \mathrm{mg} / \mathrm{liter}{ }^{125} \mathrm{I}$ albumin for varying times before washing and extraction, as described above.

To assess the effect of the PI 3-kinase inhibitors wortmannin and LY294002 on albumin endocytosis, wild-type cell monolayers were pretreated with these agents diluted from stock solutions into serumfree DME-F12 for 30 min before the addition of ${ }^{125} \mathrm{I}$-albumin. Washing and extraction of monolayers was performed as described above. To exclude an effect of the DMSO vehicle on albumin endocytosis, in parallel experiments $\mathrm{OK}$ cells were pretreated for 30 minutes with equivalent dilutions of DMSO to those used in the wortmannin and LY294002 experiments before initiation of albumin uptake.

Values for total binding of albumin to OK cell monolayers were determined by incubating with numerous concentrations of ${ }^{125} \mathrm{I}$-albumin at $4^{\circ} \mathrm{C}$ to prevent internalization, for varying times. Cells were washed, lysed, and counted as described above. All the values for albumin uptake presented have these values for albumin-binding subtracted.

Albumin recycling experiments. Recycling of endocytosed ${ }^{125} \mathrm{I}-$ albumin was measured in confluent OK cell monolayers growing in six-well plates. Wild-type or $\Delta \mathrm{p} 85$-transfected cells were quiesced for $2 \mathrm{~h}$ in serum-free DME-F12 at $37^{\circ} \mathrm{C}$. Cells were then incubated with $150 \mathrm{mg} /$ liter ${ }^{125} \mathrm{I}$-albumin at $37^{\circ} \mathrm{C}$ for $1 \mathrm{~h}$. In experiments using wortmannin and LY294002, these inhibitors were added to the cells 10 min before the end of this uptake period at concentrations of 1 and $100 \mu \mathrm{M}$, respectively. After this incubation period, the cells were rapidly cooled by washing with ice-cold PBS, pH 7.4, $3 \times 2 \mathrm{ml}$ per well. This was followed by a 5 -min acid wash at $4^{\circ} \mathrm{C}$ with $50 \mathrm{mM}$ MES, pH $5.0,150 \mathrm{mM} \mathrm{NaCl}$. Monolayers were then subjected to a final wash with $2 \mathrm{ml}$ PBS, $\mathrm{pH}$ 7.4. This washing protocol removes all free radioactivity from the wells and $\sim 80 \%$ of ${ }^{125}$ I-albumin bound to the cell surface after the uptake period. Monolayers were then warmed to $37^{\circ} \mathrm{C}$ by the addition of prewarmed serum-free DME-F12. In the inhibitor experiments, wortmannin or LY294002 were also present in this media.

Subcloning and construction of expression plasmids. The full-length cDNAs encoding the p85 and $\Delta$ p85 subunits of PI 3-kinase were amplified from their host plasmids by polymerase chain reaction. The forward and reverse primers were designed such that the resulting polymerase chain reaction product would contain the full-length coding sequence for $\mathrm{p} 85$ or $\Delta \mathrm{p} 85$ flanked by recognition sequences for NotI at each end, together with a Kozak sequence before the start codon. This product was then digested with NotI and subcloned into the NotI site of the pOPRVSICAT, which itself had been predigested with NotI. Correct orientation of the insert was confirmed by test di- 
gestion of the pOPRVSICAT/p85 and pOPRVSICAT/ $/ \mathrm{p} 85$ constructs with HindIII.

Cell transfection and selection. Plasmids were introduced into exponentially growing $\mathrm{OK}$ cells by calcium phosphate precipitation. Initially, wild-type OK cells were transfected with p3'SS encoding the Lac repressor protein, and selected in DME-F12 containing hygromycin $200 \mu \mathrm{g} / \mathrm{ml}$. A single transfected clone showing high level expression of the Lac repressor protein was selected and then further transfected with either pOPRSVICAT/p85 or pOPRSVICAT/ $/ \mathrm{p} 85$ and subjected to continuing selection in DME-F12 containing hygromycin $200 \mu \mathrm{g} / \mathrm{ml}$ together with $\mathrm{G} 418300 \mu \mathrm{g} / \mathrm{ml}$. Resistant clones were picked and screened as described below.

Screening of transfected cells. OK cells transfected with p3'SS and either $\mathrm{pOPRSVICAT} / \mathrm{p} 85$ or $\mathrm{pOPRSVICAT} / \Delta \mathrm{p} 85$ were screened by Western blotting with anti-Lac repressor protein antibodies and antip85 antibodies, respectively. Cells growing in 24-well plates were lysed in Laemmli buffer containing $60 \mathrm{mM}$ Tris, pH $6.8,10 \%$ glycerol, $2 \%$ sodium dodecyl sulphate, $100 \mathrm{mM}$ dithiothreitol, and $0.01 \%$ bromophenol blue. Proteins in cell lysates were separated by polyacrylamide gel electrophoresis and transferred to nitrocellulose membranes. Primary antibodies were used at 1:500 dilution for the anti-Lac repressor antibody, and 1:1,000 for the anti-p85 antibody. Secondary antibodies were detected using enhanced chemiluminescence (ECL) development and, where necessary, intensity of bands was determined by laser densitometry. For cells transfected with p3'SS and pOPRSVICAT/p85 or pOPRVSICAT/ $/ \mathrm{p} 85$, expression of $\mathrm{p} 85$ and $\Delta$ p85 proteins was induced by treating OK cell monolayers with IPTG in the culture medium before preparation of cell lysates.

A number of clonal cell lines demonstrating inducible expression of either $\mathrm{p} 85$ or $\Delta \mathrm{p} 85$ were selected. The results presented are derived from two such clones, each one expressing the relevant recombinant protein. These $\mathrm{p} 85$ - or $\Delta \mathrm{p} 85$-expressing cell lines were also used with and without IPTG induction for ${ }^{125} \mathrm{I}$-albumin uptake experiments as described above.

Assay of PI 3-kinase activity in transfected cells. The activity of PI 3-kinase in both p85- and $\Delta$ p85-transfected cells was measured in anti-phosphotyrosine immunoprecipitates of the cells using PtdIns and PtdIns $(4,5) \mathrm{P}_{2}$ as substrates, by an adaptation of the method of Batty et al. (36). Briefly, confluent $\mathrm{p} 85$ - or $\Delta \mathrm{p} 85$-transfected OK cells were grown in $10 \mathrm{~cm}$ petri dishes and quiesced in serum-free DMEF12 overnight before the experiment. Control cells were subjected to a serum-free DME-F12 media change, other cells were stimulated with either $10 \mu \mathrm{g} / \mathrm{ml}$ insulin or $1 \mathrm{mg} / \mathrm{ml}$ human serum albumin in serum-free DME-F12 for $5 \mathrm{~min}$ at $37^{\circ} \mathrm{C}$. The stimulation was ended by aspiration of the media and lysis of the monolayer with $1 \mathrm{ml}$ of an icecold lysis buffer consisting of $50 \mathrm{mM}$ Hepes, $\mathrm{pH} 7.5,120 \mathrm{mM} \mathrm{NaCl}$, $50 \mathrm{mM} \mathrm{NaF}, 1.5 \mathrm{mM} \mathrm{MgCl}_{2}, 1 \mathrm{mM}$ EDTA, $200 \mu \mathrm{M}$ sodium orthovanadate, $1 \mathrm{mM}$ phenylmethylsulphonyl fluoride, $10 \mu \mathrm{g} / \mathrm{ml}$ pepstatin, $10 \mu \mathrm{g} / \mathrm{ml}$ antipain, $1 \%$ Triton X-100. The monolayer was scraped and allowed to stand on ice for $20 \mathrm{~min}$. Insoluble material was removed by centrifugation. The supernatant was then precleared for 30 minutes with protein A-sepharose and then incubated for $2 \mathrm{~h}$ with $10 \mu \mathrm{PY} 20$ anti-phosphotyrosine antibodies at $4^{\circ} \mathrm{C}$. Immune complexes were incubated with rabbit anti-mouse immunoglobulins for $30 \mathrm{~min}$, and then immunoprecipitated overnight with protein $\mathrm{A}$-sepharose beads at $4^{\circ} \mathrm{C}$.

After extensive washing, protein A-sepharose was resuspended in $180 \mu \mathrm{l}$ of a kinase buffer composed of $50 \mathrm{mM}$ Hepes, $\mathrm{pH} 7.4,120 \mathrm{mM}$ $\mathrm{NaCl}, 10 \mathrm{mM} \mathrm{MgCl}_{2}$, and $200 \mu \mathrm{M}$ adenosine. Lipid substrate was prepared by dissolving $300 \mu \mathrm{g}$ PtdIns, $100 \mu \mathrm{g} \operatorname{PtdIns}(4,5) \mathrm{P}_{2}$, and $300 \mu \mathrm{g}$ phosphatidylserine each in $10 \mu \mathrm{l}$ acidified chloroform methanol (chloroform 200:methanol 400:concentrated $\mathrm{HCl} 5$, vol/vol). The dissolved lipids were mixed, dried under $\mathrm{N}_{2}$, and then rehydrated with $250 \mu \mathrm{l}$ of $20 \mathrm{mM}$ Hepes, $\mathrm{pH}$ 7.4, $2 \mathrm{mM}$ EGTA for $30 \mathrm{~min}$. This mixture was then sonicated at full power for $5 \times 15 \mathrm{~s}$ with $1 \mathrm{~min}$ on ice between each step. An aliquot of $20 \mu$ l of this sonicated lipid mix was then added to the sepharose beads resuspended in $180 \mu \mathrm{l}$ kinase buffer. The assay was started by the addition of $50 \mu \mathrm{M}$ ATP $(20 \mu \mathrm{Ci}$ $\left.\gamma\left[{ }^{32} \mathrm{P}\right] \mathrm{ATP}\right)$ and the reaction continued for $15 \mathrm{~min}$ at $37^{\circ} \mathrm{C}$. The reaction was stopped by the addition of acidified chloroform methanol solution, and lipids washed, dried, and deacylated using methylamine exactly according to Batty et al. (36). The deacylated lipid products were run on HPLC and radiolabeled reaction products detected using a $\left[{ }^{32} \mathrm{P}\right]$ flow through detector. HPLC conditions and gradients were chosen according to Batty et al. (36).

Data analysis. Curve fitting was performed by nonlinear regression using curve fitting software (GraphPad Prism, San Diego, CA).

\section{Results}

To determine whether PI 3-kinase was able to regulate albumin endocytosis in $\mathrm{OK}$ cells, we pretreated cell monolayers with the PI 3-kinase inhibitors wortmannin and LY294002. Addition of these agents to cell culture media resulted in a concentration-dependent inhibition of albumin endocytosis (Fig. 1). The $\mathrm{IC}_{50}$ for inhibition of albumin endocytosis by wortmannin is $6.9 \mathrm{nM}$, and for inhibition of albumin endocytosis by LY294002 is $6.5 \mu \mathrm{M}$. These values are in accordance with previously published values for the inhibition of PI 3-kinase by these agents $(31,32)$.

The time course of albumin uptake into OK cells under control conditions and after treatment with wortmannin and LY294002 is shown in Fig. $2 a$. In untreated cells, albumin uptake rises rapidly over time, reaching a peak after $\sim 15 \mathrm{~min}$. After this peak, a plateau steady state is reached and maintained at $30 \mathrm{~min}$ and beyond. In the cells treated with the PI 3-kinase inhibitors, there is a marked reduction in the initial phase of albumin endocytosis, such that the peak uptake of al-

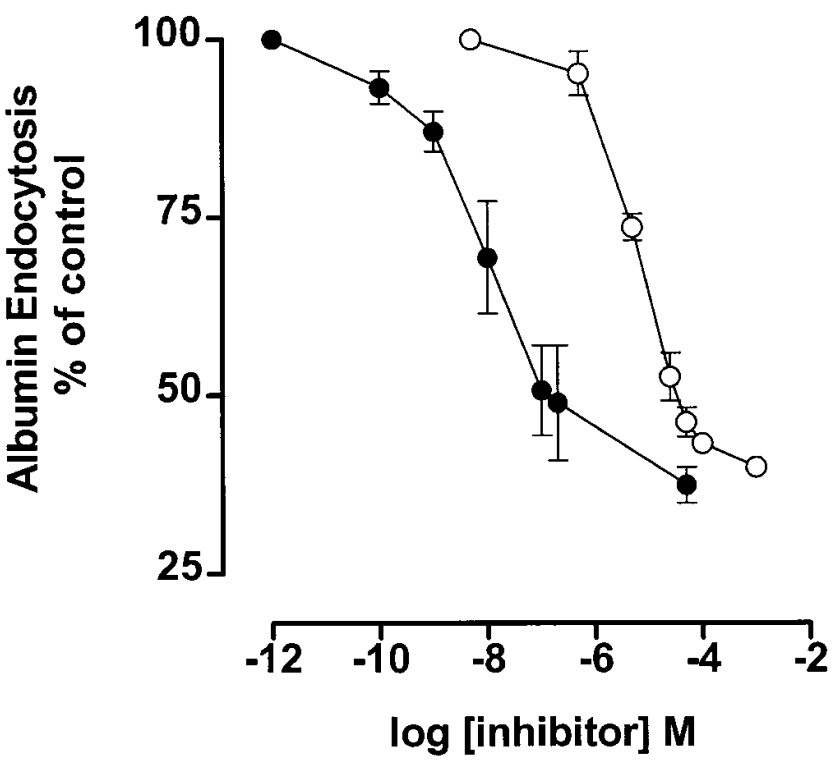

Figure 1. Wortmannin and LY294002 inhibit albumin endocytosis in OK cells. Confluent wild-type OK cells were pretreated with various concentrations of wortmannin (filled circles) or LY294002 (open circles) before initiation of ${ }^{125} \mathrm{I}$-albumin endocytosis for $15 \mathrm{~min}$ at $37^{\circ} \mathrm{C}$. Values for total binding of ${ }^{125} \mathrm{I}$-albumin to the cell surface measured at $4^{\circ} \mathrm{C}$ in separate experiments have been subtracted. Control values are given as $100 \%$ and represent ${ }^{125} \mathrm{I}$-albumin uptake into cells untreated with either wortmannin or LY294002. Data are means \pm SEM; $n=4-5$. 
(a)

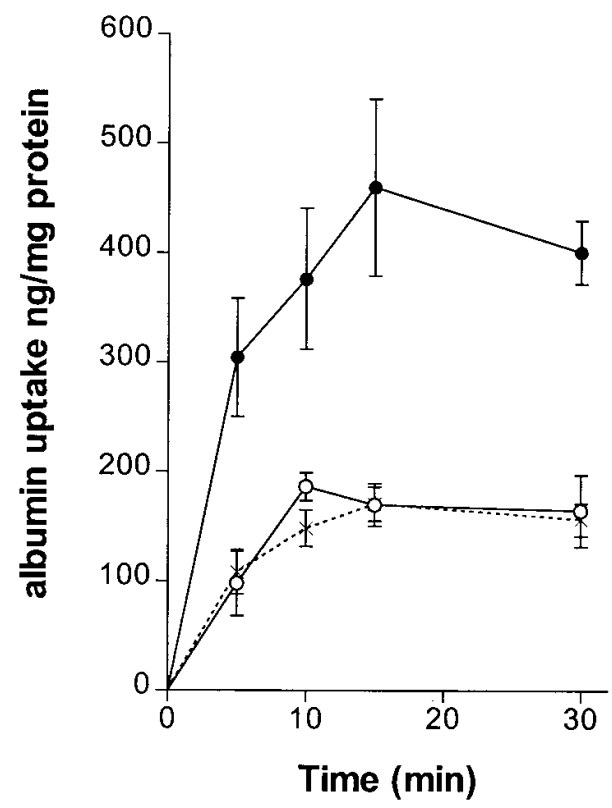

(b)

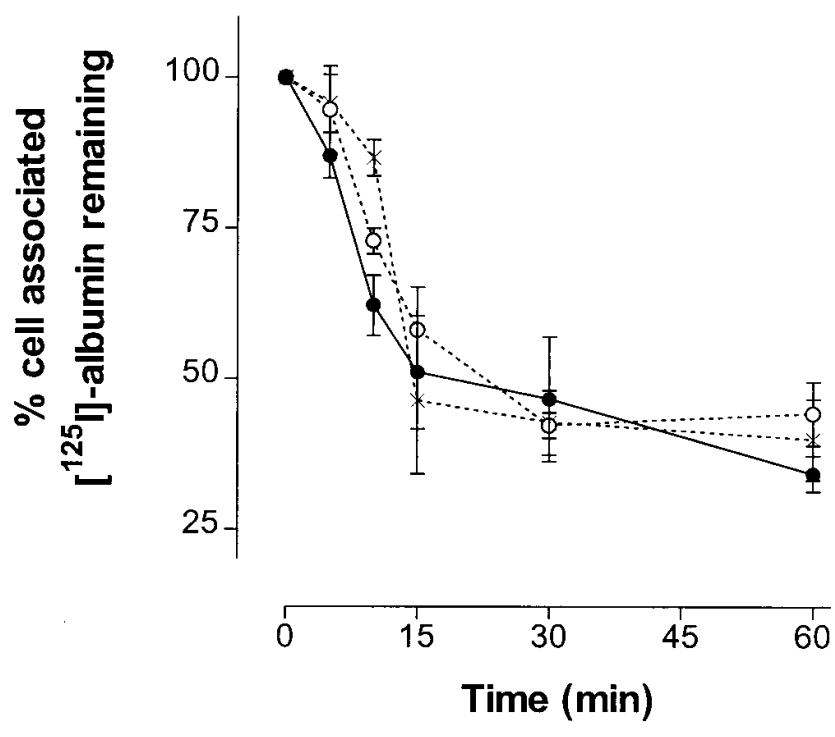

Figure 2. Time course of albumin endocytosis and recycling in $\mathrm{OK}$ cells under control conditions and after pretreatment with wortmannin or LY294002. (a) Time course of albumin endocytosis. Confluent wild-type OK cells were incubated with $150 \mathrm{mg} / \mathrm{liter}{ }^{125} \mathrm{I}$-albumin at $37^{\circ} \mathrm{C}$ for various times. Cells had no pretreatment (controls, filled circles), or were pretreated with either $1 \mu \mathrm{M}$ wortmannin (open circles) or $100 \mu \mathrm{M}$ LY294002 (broken line) for $30 \mathrm{~min}$ before the initiation of ${ }^{125} \mathrm{I}$-albumin endocytosis. At each time point, endocytosis was terminated by washing with ice-cold PBS, and the cell monolayer extracted and counted. Values for total binding of ${ }^{125} \mathrm{I}$-albumin to OK cell monolayers at $4^{\circ} \mathrm{C}$ were determined for each time point in separate experiments and have been subtracted from this data. Data represent means \pm SEM for $n=3-5$ experiments. (b) Albumin recycling in wildtype OK cells under control conditions and after treatment with either wortmannin (open circles) or LY294002 (broken line). Confluent monolayers of cells were allowed to endocytose $150 \mathrm{mg} / \mathrm{liter}{ }^{125} \mathrm{I}$-albu$\min$ for $1 \mathrm{~h}$ at $37^{\circ} \mathrm{C}$. Some cells were treated with PI 3-kinase inhibitors for the final $10 \mathrm{~min}$ of this uptake period. Monolayers were cooled and acid washed to remove surface bound ${ }^{125}$ I-albumin, re- bumin endocytosis is reduced by $\sim 70 \%$ of control values. The later part of the time course in the inhibitor-treated cells is qualitatively very similar to that seen in the control cells with the plateau occurring at an equivalent time point. Recycling of endocytosed albumin is depicted in Fig. $2 b$. The rates of albumin recycling are very similar in untreated control cells and those cells treated with either wortmannin or LY294002.

These results, therefore, suggested that PI 3-kinase was a regulator of the endocytic pathway for albumin in OK cells. However, neither wortmannin nor LY294002 are completely specific in their actions. Therefore, we decided to use a p85 dominant negative mutant $(\Delta \mathrm{p} 85)$ to inhibit the activity of PI 3-kinase in OK cells with greater specificity. Unregulated expression of $\Delta \mathrm{p} 85$ in cells could potentially have profound and unwanted effects on cell growth. Therefore, we wished to express $\Delta \mathrm{p} 85$ in an inducible form using the LacSwitch expression system, where under basal conditions gene expression is repressed, but expression can be induced by IPTG. To construct a suitable vector, the cDNA for bovine $\Delta \mathrm{p} 85$ was cloned into the NotI site of pOPRVISCAT and this construct transfected into $\mathrm{OK}$ cells stably expressing $\mathrm{p}^{\prime} \mathrm{SS}$. As a control, other cells were transfected with a normal wild-type p85 subunit, also under the regulation of the LacSwitch.

Transfected cells were screened using two different antip85 antisera. One was a monoclonal antibody that did not recognize the endogenous p85 subunit in OK cells. Using this antibody, we observed no expression of either $\mathrm{p} 85$ or $\Delta \mathrm{p} 85$ proteins by immunoblotting of cell lysates derived from transfected cells not exposed to IPTG. When $5 \mathrm{mM}$ IPTG was added to the culture medium expression of both, the p 85 and $\Delta \mathrm{p} 85$ proteins were detectable after $4 \mathrm{~h}$ (Fig. $3 a$ ). This induction of expression reached a maximum after $18 \mathrm{~h}$ as depicted for $\Delta \mathrm{p} 85$ in Fig. $3, b$ and $c$. The $\mathrm{EC}_{50}$ for induction of $\Delta \mathrm{p} 85 \mathrm{ex}-$ pression by IPTG was $13.7 \mu \mathrm{M}$ (Fig. $3 d$ ). The $\mathrm{EC}_{50}$ value for expression of p85 by IPTG was very similar, with induction also being maximal after $18 \mathrm{~h}$ (results not shown).

The second anti-p85 antibody was polyclonal and recognized both the endogenous and transfected bovine p85 subunits. Using this antibody, we were able to demonstrate that after $18 \mathrm{~h}$ of treatment with $5 \mathrm{mM}$ IPTG, transfected OK cells expressed either the $\mathrm{p} 85$ or $\Delta \mathrm{p} 85$ proteins at a 10 -fold excess over the endogenous p85 subunit of PI 3-kinase (data not shown).

Having established inducible expression of p85 and $\Delta \mathrm{p} 85$ in OK cells we used an in vitro PI 3-kinase assay to assess the effect of overexpression of these subunits on PI 3-kinase activity. Transfected OK cells, either noninduced or induced by IPTG for $18 \mathrm{~h}$ were immunoprecipitated by anti-phosphotyrosine antibodies under control conditions or after stimulation by insulin. The immunoprecipitate was then used to phosphorylate PtdIns and PtdIns $(4,5) \mathrm{P}_{2}$ in the presence of $\gamma\left[{ }^{32} \mathrm{P}\right]$-ATP. A series of representative experiments is depicted in Fig. 4. In quiescent, noninduced $\Delta \mathrm{p} 85$ cells immunoprecipitated under control conditions, no phosphorylated reaction products are identified by HPLC (Fig. $4 a$ ). When noninduced $\Delta$ p85-transfected are cells are stimulated by insulin, three peaks can be

warmed to $37^{\circ} \mathrm{C}$ and the remaining radioactivity associated with the cells was measured after various times. Data represent means \pm SEM for $n=3-4$ experiments. 
(a)

IPTG

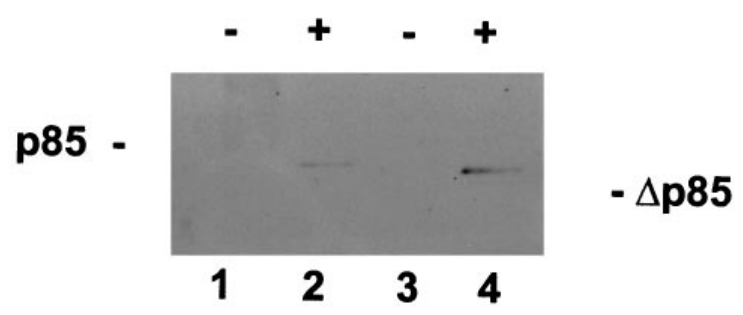

(b)

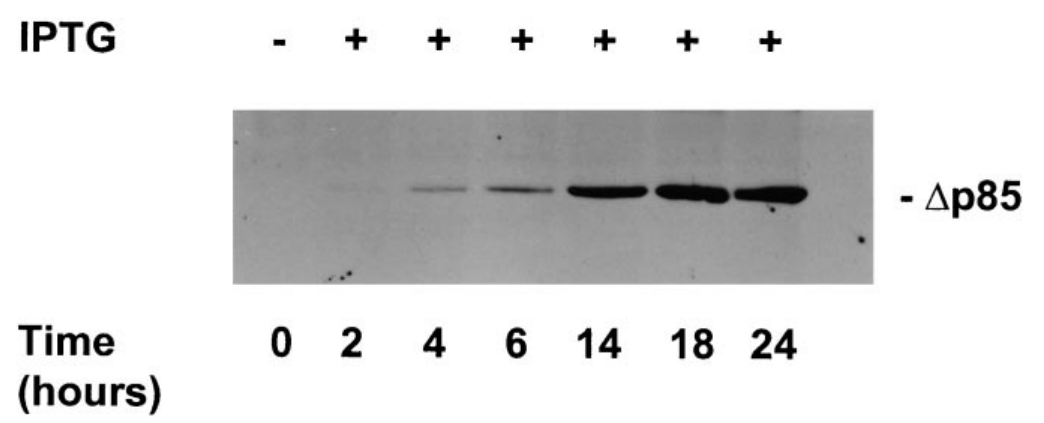

(c)

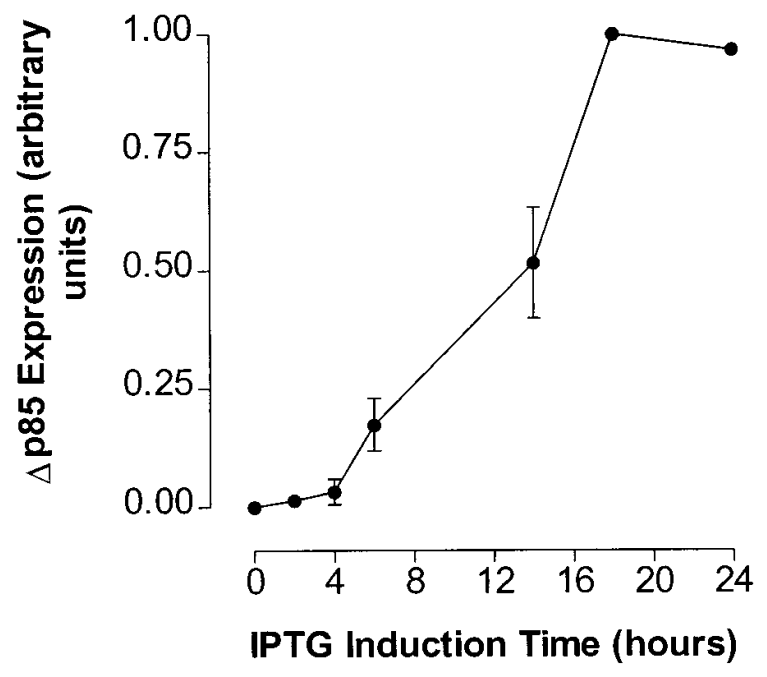

(d)

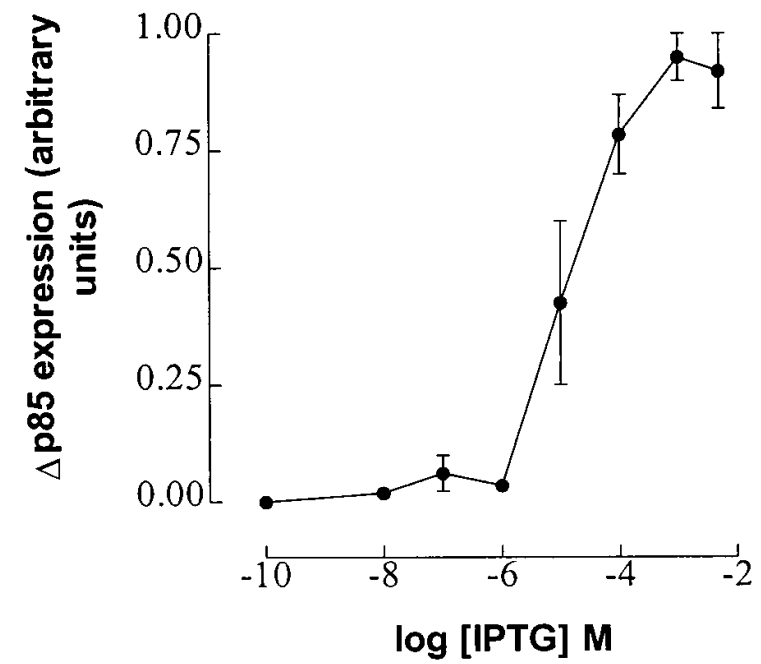

Figure 3. Inducible expression of $\mathrm{p} 85$ and $\Delta \mathrm{p} 85$ constructs by IPTG in OK cells. Cells were transfected with the cDNA for either p85 or $\Delta \mathrm{p} 85$ under the control of the LacSwitch. Transfected cell lysates were screened by immunoblotting with monoclonal anti-PI 3-kinase antibodies using an ECL development system. The antibody used in these experiments does not recognize the endogenous p85 protein in OK cells. (a) Cells transfected with p85 (lanes 1 and 2) or $\Delta$ p85 (lanes 3 and 4) were screened before exposure to IPTG, or after exposure to 5 mM IPTG in the culture medium for $6 \mathrm{~h}$. This blot is representative of at least three blots performed each using cell lysates from different IPTG induction experiments. (b) $\Delta$ p85-transfected cells were screened before exposure to IPTG (time, $0 \mathrm{~h}$ ), or after increasing times of exposure to $5 \mathrm{mM}$ IPTG in the culture medium. This is a representative blot of at least three blots performed, each using cell lysates derived from different IPTG induction experiments. (c) Time dependence of $\Delta$ p85 induction by IPTG in transfected OK cells. $\Delta$ p85-transfected cell lysates were immunoblotted with monoclonal anti-p85 antibodies after various times of $5 \mathrm{mM}$ IPTG induction, and developed using ECL. Bands representing $\Delta$ p 85 protein were quantified by laser densitometry, with the quantity of $\Delta \mathrm{p} 85$ protein present after $24 \mathrm{~h}$ of IPTG induction being arbitrarily assigned the value 1.0. Data represent means \pm SEM for densitometry readings derived from at least three different blots each using a cell lysate derived from different IPTG induction experiments. $(d)$ Dependence of $\Delta \mathrm{p} 85$ induction on IPTG concentration. $\Delta \mathrm{p} 85$-transfected cells were immunoblotted with monoclonal anti-p85 antibodies after $24 \mathrm{~h}$. Bands representing $\Delta \mathrm{p} 85$ protein were quantified by laser densitometry, with the quantity of $\Delta \mathrm{p} 85$ protein present after $24 \mathrm{~h}$ of induction with $5 \mathrm{mM}$ IPTG being arbitrarily assigned the value 1.0. Data represent means \pm SEM for densitometry readings derived from at least three different blots, each using a cell lysate derived from different IPTG induction experiments. 
(a)

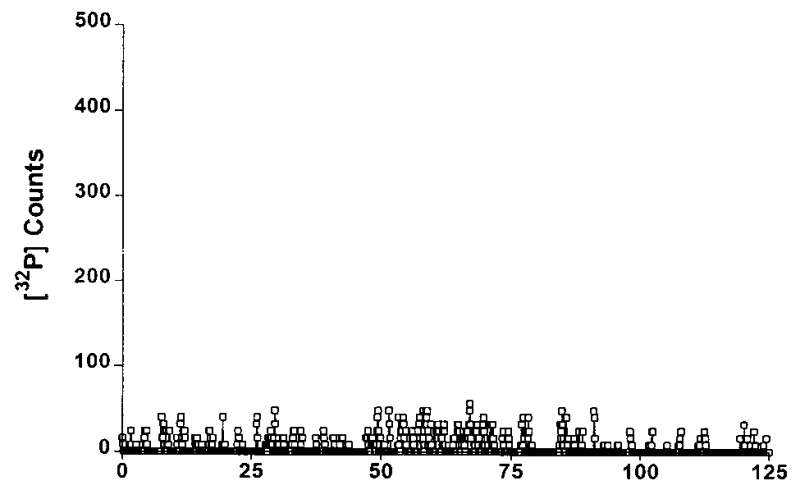

(b)

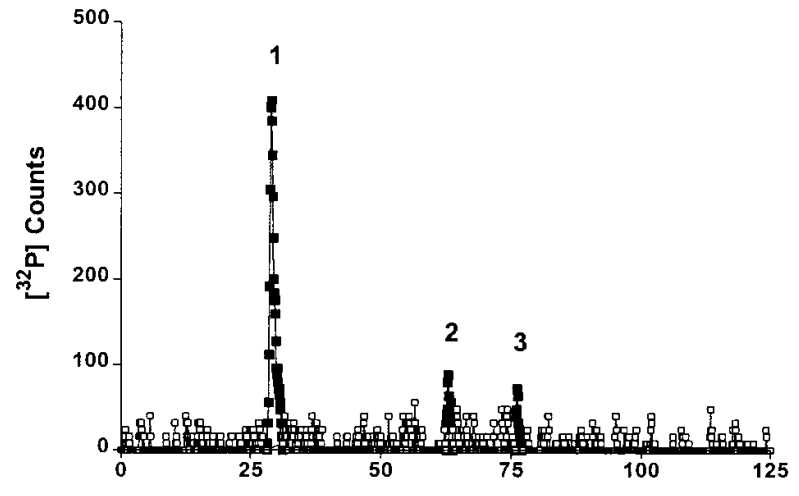

(d)

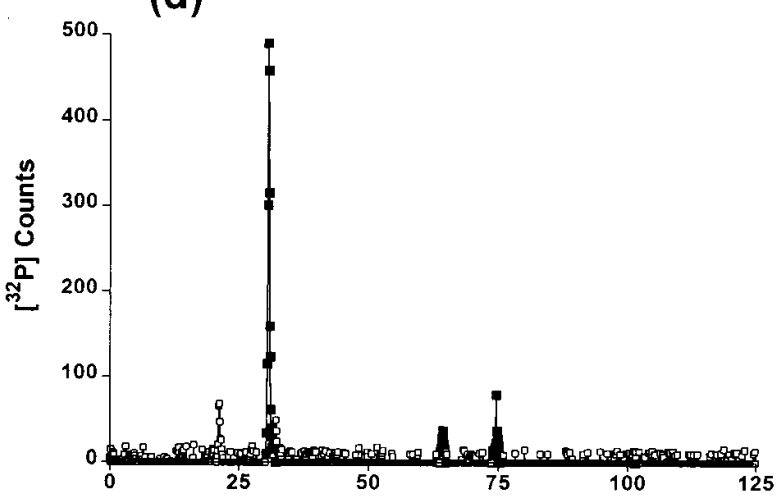

(e)

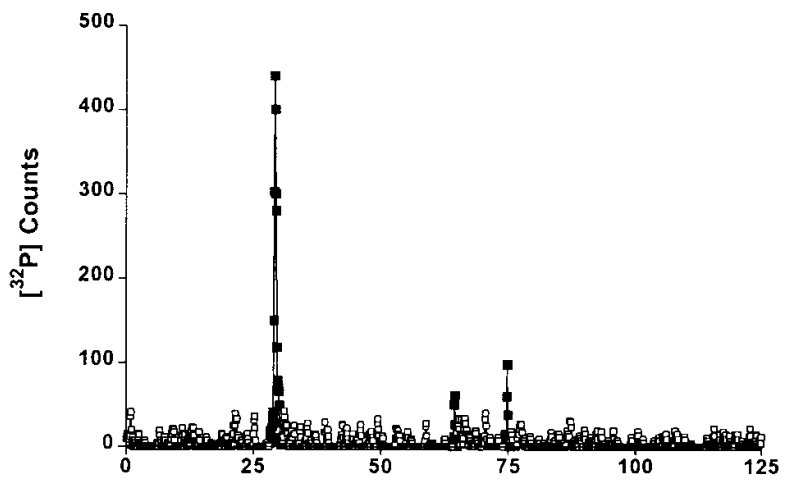

\section{Elution Time (min)}

(c)

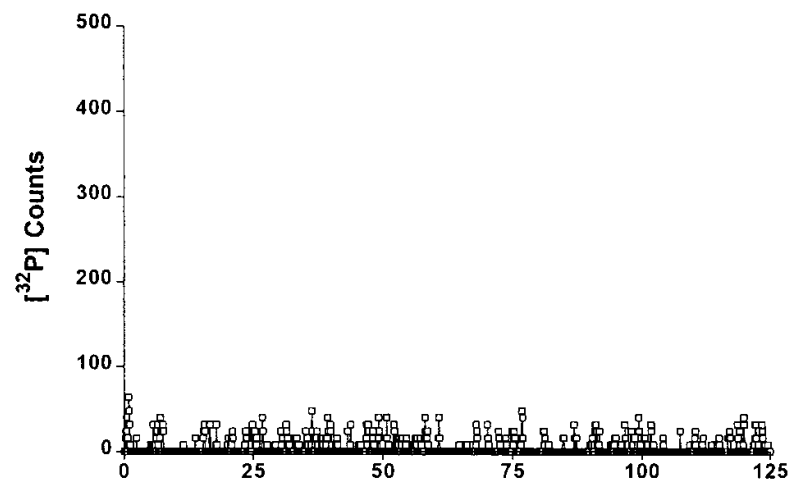

Elution Time ( $\mathrm{min})$
Figure 4. In vitro assay for PI 3-kinase activity in $\mathrm{p} 85$ - and $\Delta \mathrm{p} 85$-transfected OK cells. The activity of PI 3-kinase was measured in anti-phosphotyrosine immunoprecipitates derived from either $\mathrm{p} 85$ - or $\Delta \mathrm{p} 85$-transfected OK cells with or without IPTG induction, and with or without prestimulation with insulin or albumin. (a) Non-IPTG induced $\Delta \mathrm{p} 85$ control cells with no pretreatment, $(b)$ non-IPTG induced $\Delta \mathrm{p} 85$ cells pretreated with $10 \mu \mathrm{g} / \mathrm{ml}$ insulin, (c) $\Delta \mathrm{p} 85$ cells induced with $5 \mathrm{mM}$ IPTG for $18 \mathrm{~h}$ followed by $10 \mu \mathrm{g} / \mathrm{ml}$ insulin stimulation, (d) p85-transfected cells induced with $5 \mathrm{mM}$ IPTG for $18 \mathrm{~h}$ and stimulated with $10 \mu \mathrm{g} / \mathrm{ml}$ insulin, and (e) non-IPTG induced $\Delta \mathrm{p} 85$-transfected cells treated with $1 \mathrm{~g} /$ liter albumin. Substrates provided were PtdIns and PtdIns(4,5) $\mathrm{P}_{2}$. Lipids were deacylated and run on HPLC. Representative elution profiles are depicted above. In the insulin-stimulated non-IPTG induced $\Delta \mathrm{p} 85$ cells $(b)$ three elution peaks are observed. Peak 1 is PtdIns(3)P. Peak 2 is PtdIns(3,4) $\mathrm{P}_{2}$. Peak 3 is $\operatorname{PtdIns}(3,4,5) \mathrm{P}_{3}$. These peaks are not observed in noninsulin-treated control $\Delta \mathrm{p} 85$ cells $(a)$, and are completely abolished in IPTG induced $\Delta \mathrm{p} 85$ expressing cells $(c)$. Identical peaks are observed after treatment of nonIPTG induced $\Delta \mathrm{p} 85$ cells with albumin $(e)$. Expression of $\mathrm{p} 85$ has no effect on the phosphorylation of these lipids by PI 3-kinase $(d)$. 
resolved by HPLC. The first peak represents PtdIns(3)P, the second PtdIns $(3,4) \mathrm{P}_{2}$, and the third PtdIns $(3,4,5) \mathrm{P}_{3}$ (Fig. $4 b$ ). When $\Delta \mathrm{p} 85$ cells are induced for $18 \mathrm{~h}$ by $5 \mathrm{mM}$ IPTG, stimulated by insulin, and immunoprecipitated, these peaks are abolished indicating that $\Delta \mathrm{p} 85$ expression results in inhibition of PI 3-kinase activity (Fig. 4 c). Stimulation by insulin of cells transfected with p85, but not induced by IPTG treatment, results in the production of the same three phosphorylated lipid products in this kinase reaction (results not shown). In contrast to the results seen with $\Delta \mathrm{p} 85$ transfects, when IPTG is used to induce expression of $\mathrm{p} 85$, the insulin-stimulated PI 3-kinase activity associated with anti-phosphotyrosine immunoprecipitates is unchanged (Fig. $4 d$ ). It is very interesting to see that pretreatment of cells with albumin also results in the association of PI 3-kinase activity with anti-phosphotyrosine immunoprecipitates in noninduced $\Delta$ p85-transfected cells (Fig. $4 e$ ). This activity is also abolished on induction of $\Delta \mathrm{p} 85$ expression (results not shown).

Induction of $\Delta \mathrm{p} 85$ expression by IPTG has a profound effect on the endocytosis of ${ }^{125} \mathrm{I}$-albumin. As the level of $\Delta \mathrm{p} 85$ protein expression rises in response to increasing length of exposure to IPTG, there is a concomitant reduction in ${ }^{125} \mathrm{I}$-albumin endocytosis (Fig. 5). This fall in albumin endocytosis mirrors the rise in expression of $\Delta \mathrm{p} 85$ very closely. Changes in the level of expression of $\Delta \mathrm{p} 85$ do not alter the binding of ${ }^{125} \mathrm{I}$ albumin to the surface of the OK cells, and the addition of wortmannin to these cells did not lead to a greater reduction

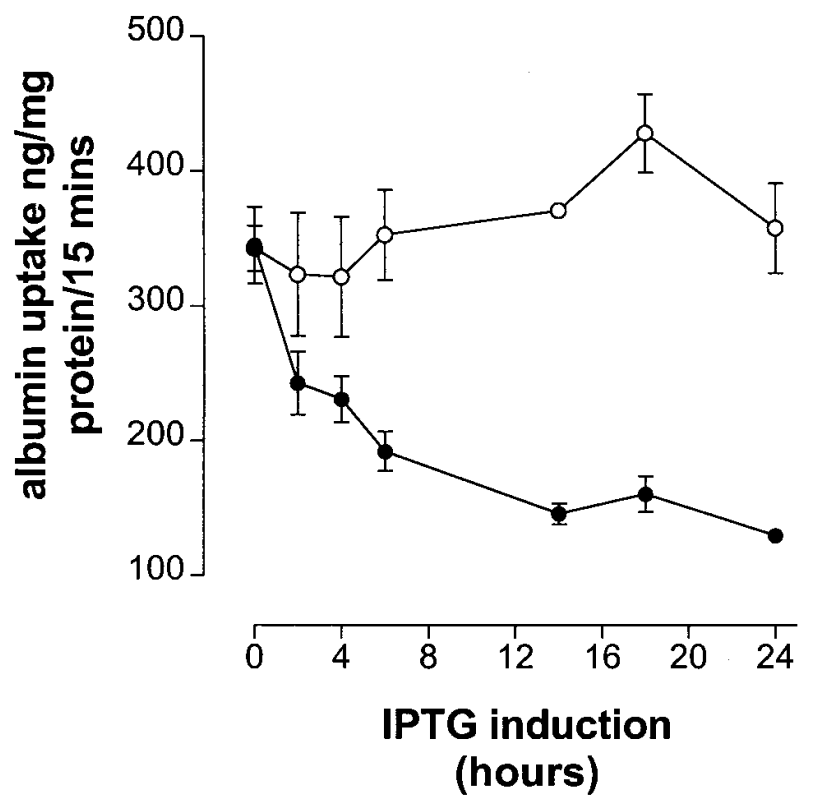

Figure 5. [ $\left.{ }^{125} \mathrm{I}\right]$-Albumin endocytosis in OK cells expressing $\mathrm{p} 85$ or $\Delta \mathrm{p} 85$. OK cells transfected with $\mathrm{p} 85$ or $\Delta \mathrm{p} 85$ under the control of LacSwitch were grown to confluence in six-well plates in the absence of IPTG. Albumin endocytosis was measured using $150 \mathrm{mg} /$ liter ${ }^{125} \mathrm{I}$-albumin at $37^{\circ} \mathrm{C}$ for $15 \mathrm{~min}$ in these cells without prior treatment with IPTG, or after pretreatment with IPTG for various lengths of time. Cells transfected with p85 are depicted by open circles, and those transfected with $\Delta \mathrm{p} 85$ are represented by closed circles. Values for total binding of ${ }^{125} \mathrm{I}$-albumin to the cell surface measured in separate experiments have been subtracted from this data. Data represent means \pm SEM; $n=4-5$.

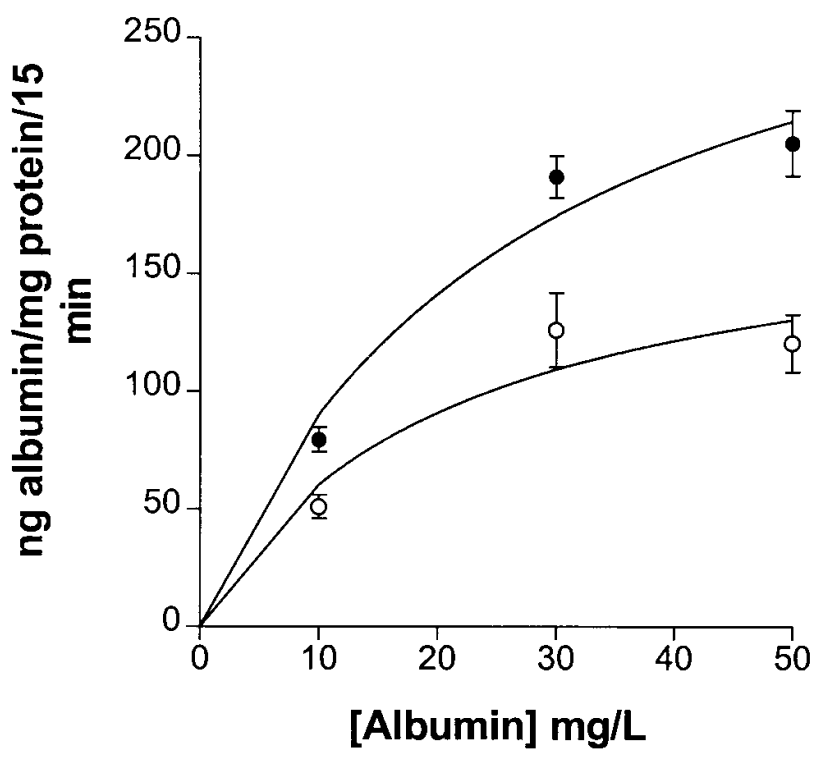

Figure 6. Concentration dependency of $\left[{ }^{125} \mathrm{I}\right]$-albumin uptake into $\Delta \mathrm{p} 85$-transfected cells. OK cells transfected with $\Delta \mathrm{p} 85$ under the control of LacSwitch were grown to confluence in 6-well plates in the absence of IPTG. ${ }^{125}$ I-albumin uptake was then measured in these cells without IPTG induction (filled circles), or after IPTG induction for $6 \mathrm{~h}$ (empty circles). Various concentrations of ${ }^{125} \mathrm{I}$-albumin were used and endocytosis was allowed to continue for $15 \mathrm{~min}$ at $37^{\circ} \mathrm{C}$. Values for total binding of ${ }^{125} \mathrm{I}$-albumin at each incubated concentration were measured at $4^{\circ} \mathrm{C}$ in separate experiments and have been subtracted from this data. Data are means \pm SEM; $n=3$.

in albumin uptake than that observed with $\Delta \mathrm{p} 85$ expression alone (data not shown). In contrast, increasing levels of expression of $\mathrm{p} 85$ have no significant effect on the endocytosis of ${ }^{125} \mathrm{I}$-albumin (Fig. 5). The data displayed in Fig. 6 demonstrate that the reduction in the rate of $\left[{ }^{125} \mathrm{I}\right]$-albumin uptake in $\Delta \mathrm{p} 85$ cells is due largely to a fall in $\mathrm{V}_{\max }$ for the uptake process rather than a change in the $K_{\mathrm{m}}$ for albumin. The $K_{\mathrm{m}}$ for albumin endocytosis in non-IPTG induced cells is $26.6 \mathrm{mg} /$ liter, and in IPTG-induced cells $21.43 \mathrm{mg} / \mathrm{liter}$. These values are in close agreement with previously published values in wild-type OK cells (9).

The time course of ${ }^{125} \mathrm{I}$-albumin uptake into $\Delta \mathrm{p} 85$ cells induced for $6 \mathrm{~h}$ by $5 \mathrm{mM}$ IPTG (Fig. $7 a$ ) is very similar to that seen in the presence of wortmannin and LY294002. Uptake reaches a maximum after 10-15 min followed by a plateau. The major reduction in endocytosis seen in $\Delta$ p85 expressing cells is accounted for by marked attenuation of initial rates of endocytosis, the plateau phase being qualitatively similar in noninduced and induced cells. When ${ }^{125}$ I-albumin recycling rates are studied (Fig. $7 b$ ), it can be seen that little difference exists between non-IPTG-induced and IPTG-induced $\Delta$ p85 cells.

\section{Discussion}

The endocytosis of macromolecules is a prominent function of the kidney proximal tubule epithelium. Despite a wealth of descriptive morphological studies that have carefully delineated the intracellular pathway followed by various endocytosed 
(a)
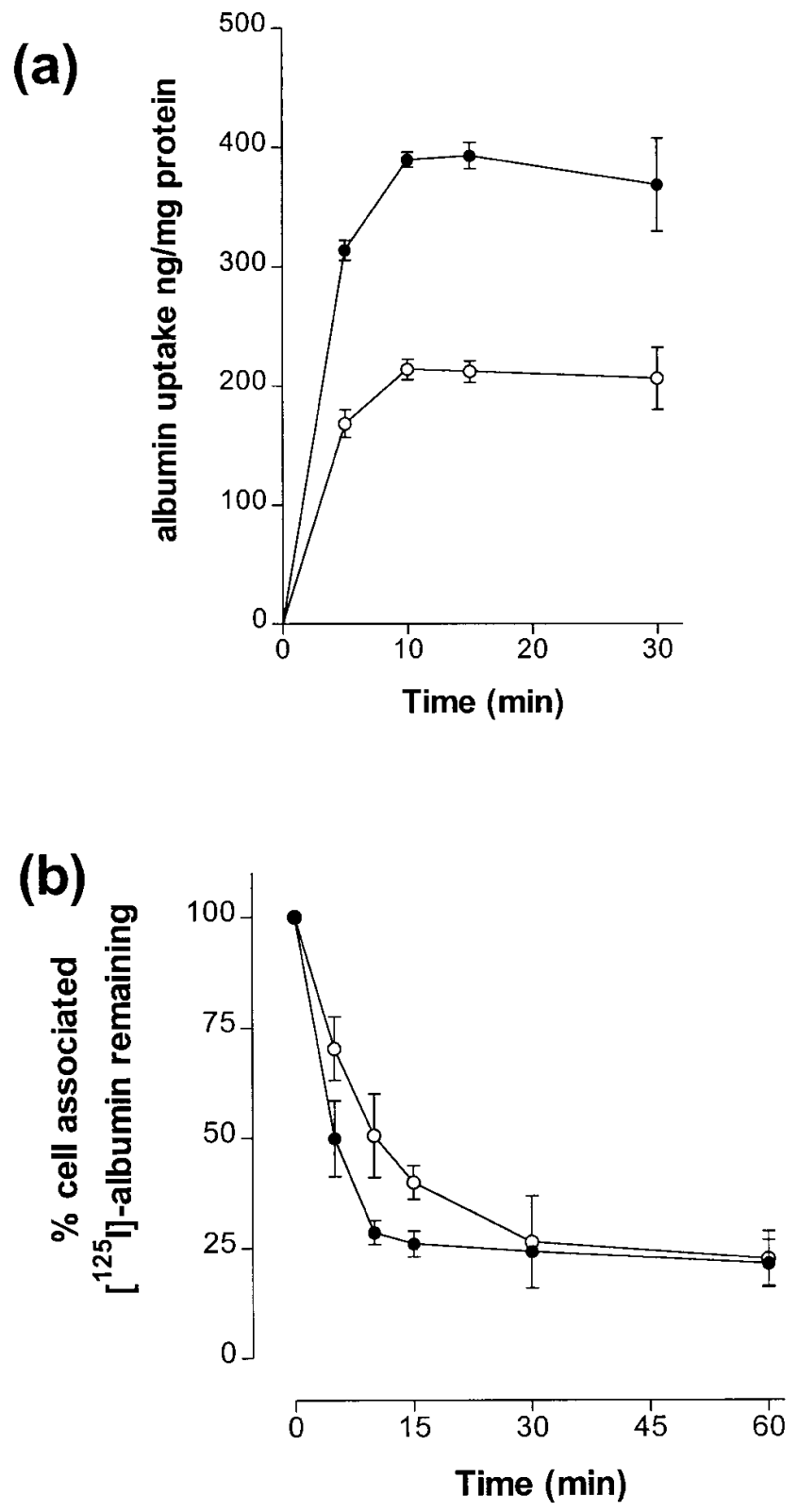

Figure 7. Time course of ${ }^{125} \mathrm{I}$-albumin uptake and recycling into $\Delta$ p85-transfected OK cells. (a) Time course of albumin endocytosis. OK cells transfected with $\Delta \mathrm{p} 85$ under the control of LacSwitch were grown to confluence in six-well plates in the absence of IPTG. ${ }^{125} \mathrm{I}$ albumin uptake was then measured in these cells without IPTG induction (filled circles), or after IPTG induction for $6 \mathrm{~h}$ (empty circles). Endocytosis was allowed to continue for various times up to $30 \mathrm{~min}$ in the absence of IPTG. The concentration of ${ }^{125} \mathrm{I}$-albumin was $150 \mathrm{mg} /$ liter in all experiments. Values for total binding of ${ }^{125} \mathrm{I}$-albumin to the cell surface measured in separate experiments have been subtracted from this data. Data represent means \pm SEM; $n=4$. (b) Albumin recycling in $\Delta \mathrm{p} 85$-transfected cells. Non-IPTG-induced $\Delta \mathrm{p} 85$ cells (filled circles) or $\Delta \mathrm{p} 85$ cells induced by $5 \mathrm{mM}$ IPTG for $6 \mathrm{~h}$ (open circles) were allowed to endocytose $150 \mathrm{mg} / \mathrm{liter}{ }^{125} \mathrm{I}$-albumin for $1 \mathrm{~h}$ at $37^{\circ} \mathrm{C}$. Cells were then cooled and acid washed to remove surface bound ${ }^{125} \mathrm{I}$-albumin, and then rewarmed to $37^{\circ} \mathrm{C}$ and the remaining radioactivity associated with the cells was measured after various times. Data represent means \pm SEM for $n=$ three to four experiments. proteins (for review see reference 7), little information is available regarding the regulation of these vesicular-trafficking pathways in the proximal tubule. Numerous authors have studied endocytic pathways in renal tubular epithelial cells, most usually MDCK cells $(37,38)$, but this cell type displays characteristics most reminiscent of distal tubular segments (39). We chose to continue our studies of albumin endocytosis in the proximal tubule-derived $\mathrm{OK}$ cell line. This is an established immortalized kidney cell line with prominent proximal tubular characteristics $(40,41)$. It has been used by others in the study of albumin endocytosis (8). In particular, we wished to examine the potential for interaction of pathways of endocytic regulation with mechanisms of growth regulation in the proximal tubule.

Demonstration of inhibition of a cellular event by the PI 3-kinase inhibitors wortmannin at low nanomolar concentrations, and LY294002 at low micromolar concentrations, has conventionally led authors to implicate PI 3-kinase as a regulator of the event in question. Particularly for wortmannin, however, there is now a growing list of enzymes which can also be inhibited by this agent. Whereas the majority of these targets are only inhibited by higher concentrations of wortmannin than those necessary for the inhibition of PI 3-kinase, the recent demonstration of inhibition of phospholipase $A_{2}$ by $2 \mathrm{nM}$ wortmannin (35) means that experimental results obtained with this agent alone have to be interpreted with caution, and indeed data derived from experiments using only this compound may need to be re-evaluated.

In addition to our data derived from the use of wortmannin, powerful supporting evidence for a regulatory role of PI 3-kinase in the regulation of albumin endocytosis in OK cells was provided by the results using LY294002. This agent inhibited albumin endocytosis with an $\mathrm{IC}_{50}$ in the low micromolar range, thus conforming to the published potency of this compound for PI 3-kinase inhibition (42). Although undoubtedly an inhibitor of PI 3-kinase, the specificity of LY294002 has not been subject to the same degree of scientific scrutiny as that of wortmannin and thus there remains a possibility that other intracellular targets for LY294002 inhibition may exist. Nonetheless, the combination of results obtained using both wortmannin and LY294002 provide compelling evidence that PI 3-kinase does indeed regulate endocytosis of albumin.

To circumvent this problem of inhibitor nonspecificity, we expressed $\Delta \mathrm{p} 85$ under the control of the LacSwitch. This approach has been previously shown to inhibit PI 3-kinase activity and has been utilized to elucidate the role of PI 3-kinase in insulin-stimulated glucose transport (28). Tight repression of $\Delta \mathrm{p} 85$ expression was achieved in the basal state by LacSwitch, thus eliminating any confounding effects of $\Delta$ p85 expression on cell growth. Other cells were transfected with a wild-type p85 subunit in a similarly inducible manner as a control.

The in vitro kinase assay clearly demonstrates that PI 3-kinase activity becomes associated with tyrosine phosphorylated proteins in $\mathrm{OK}$ cells subjected to appropriate agonist stimulation. The observed in vitro specificity of p85/p110 PI 3-kinase differs from that observed in vivo, such that in vitro the enzyme is able to phosphorylate both PtdIns and PtdIns $(4,5) \mathrm{P}_{2}$, whereas in vivo specificity is restricted to phosphorylation of $\operatorname{PtdIns}(4,5) \mathrm{P}_{2}$. It is thought that this variability in substrate specificity is a consequence of differing substrate presentation (43). Hence, the profile of lipid phosphorylation observed in these experiments, which results in the production 
of PtdIns(3)P and PtdIns $(3,4,5) \mathrm{P}_{3}$, is consistent with this PI 3-kinase activity resulting from the action of p85/p110 PI 3-kinase in an in vitro assay. Additional support for this contention is provided by the observation that expression of $\Delta \mathrm{p} 85$ but not $\mathrm{p} 85$ inhibits the PI 3-kinase activity associated with tyrosine phosphorylated proteins in response to insulin stimulation as described by Hara et al. (28). Using a similar approach, these authors also demonstrated inhibition of insulin-stimulated p85/p110 PI 3-kinase activity in cells expressing $\Delta \mathrm{p} 85$ but not $\mathrm{p} 85$ (28).

The observed stimulation of PI 3-kinase activity by albumin is of considerable interest. The results clearly demonstrate that pretreatment of cells with albumin leads to the association of PI 3-kinase activity with tyrosine phosphorylated proteins. Albumin has not traditionally been considered to be a signaling molecule in its own right, but recent evidence has led to this assumption being challenged. Zoellner et al. have reported that endothelial cells can be protected from apoptosis induced during serum starvation by exposure to albumin in the cell culture medium (44). Although the mechanism of this effect was not examined by these authors, a potential mechanistic clue is provided by another recent study (45). Tirrupathi et al. examined the properties of the albumin-binding protein, Gp60, in endothelial cells. Tyrosine phosphorylation of Gp60 was observed to occur after binding of albumin, followed by the recruitment to it of several $\mathrm{SH} 2$ domain-possessing proteins (45). Certainly the interaction of PI 3-kinase via the SH2 domain of $\mathrm{p} 85$ with tyrosine phosphorylated proteins as demonstrated in the current study would be consistent with these observations. In addition PI 3-kinase activity has documented importance in the prevention of apoptosis in some systems (46, 47). The findings in the current study are therefore consistent with these observations in endothelia, and suggest a potential role for albumin in the pathophysiology of proteinuric states. Albumin stimulation of PI 3-kinase activity in kidney proximal tubular cells is currently the subject of intense research in our laboratory.

The results of this study demonstrate that the activity of the p85/p110 PI 3-kinase heterodimer is able to regulate the receptor-mediated endocytosis of albumin from the apical membrane of the proximal tubular cell. Fluid phase endocytosis contributes only a tiny fraction of the total albumin endocytosis by these cells under these conditions $(8,9)$, and therefore these results cannot be explained by PI 3-kinase inhibition of fluid phase endocytosis. Rather, the PI 3-kinase enzyme appears to regulate the $V_{\max }$ of the endocytic process rather than modulate the affinity of the process for albumin. Time course studies indicate that it is primarily an early event in the endocytic pathway that is regulated by PI 3-kinase, and are consistent with the effect of PI 3-kinase inhibition being to decrease the albumin internalization rate thus reducing the volume of the early endosomal compartment. Recycling rates of endocytosed albumin are unaffected by PI 3-kinase inhibition.

Binding of albumin to the cell surface is unaffected by PI 3-kinase activity modulation. However, the rate of internalization is clearly reduced and fails to reach the peak seen with untreated cells. It seems reasonable to assume that the peak of albumin uptake represents filling of the early endosomal compartment as internalization of albumin exceeds its lysosomal hydrolysis. Therefore the volume of the early endosomal compartment appears to be reduced on inhibition of PI 3-kinase. Furthermore, the time course of albumin uptake seen in wildtype cells in the presence of wortmannin and LY294002 is very similar to that seen in the cells expressing $\Delta p 85$, indicating that the alterations in albumin endocytosis seen with the inhibitors are indeed due to p85/p110 PI 3-kinase inhibition.

Several other authors have implicated PI 3-kinase in the regulation of early steps in endocytosis. In macrophages closure of macropinosomes and phagosomes, together with their subsequent endocytosis, is blocked by PI 3-kinase inhibitors (30). Studies using mutant forms of platelet-derived growth factor receptors expressed in HepG2 cells have established that in this system PI 3-kinase regulates the passage of internalized receptors from early endosomes to lysosomes, but is not required for receptor internalization itself (48). Wortmannin also blocks intracellular accumulation of transferrin receptors in $\mathrm{CHO}$ cells transfected with the gene encoding the human protein (49). In addition to its effects on receptor-mediated endocytosis, pretreatment with wortmannin also reduces the initial rate of fluid phase uptake of horseradish peroxidase into BHK cells (31). Treatment of early endosomes with wortmannin and LY294002 inhibits their fusion in a cell-free fusion assay $(32,49)$. Invasion of cells by bacteria, a process with parallels to endocytic events, has also been shown to be inhibited by maneuvres which downregulate the formation of PtdIns(3,4,5) $\mathrm{P}_{3}(50)$, including the use of dominant negative mutants in addition to PI 3-kinase inhibitors.

Other lines of evidence suggest a role for PI 3-kinase in the regulation of membrane traffic later in the endocytic pathway. Examination of the effect of wortmannin on the localization of lysosomal type I integral membrane glycoproteins in NRK cells has suggested that PI 3-kinase activity regulates membrane traffic between late endosomes and lysosomes (51). In our albumin uptake time course studies the peak and plateau is seen at an identical time in the control cells and the PI 3-kinase inhibited cells, with no alteration in recycling rates. This observation suggests that the transfer of albumin to the lysosomal compartment, where it is broken down to its constituent amino acids, is not affected by this treatment in the OK cell system.

A number of intracellular targets for the $3^{\prime}$ phosphorylated phosphoinositides have been identified, and current evidence strongly implicates these interactions in the regulation of coated pit assembly and trafficking (for review see 52). Highaffinity binding of PtdIns (3)P and PtdIns $(3,4,5) \mathrm{P}_{3}$ to the clathrin adaptor protein AP-2 has been described $(52,53)$. AP-2 is involved in assembling clathrin-coated pits at the plasma membrane, and these observations suggest that these phospholipids may modulate protein-protein interactions at, or around the coated pit and endosome. We have observed gold-labeled albumin bound in clathrin-coated pits on the surface of OK cells (our unpublished observations). Although not directly examined in the current study, the results are consistent with the notion of an interaction of the $3^{\prime}$ phosphorylated phosphoinositides with AP-2 in the regulation of receptor-mediated endocytosis through clathrin-coated pits.

It is interesting to speculate as to whether the PI 3-kinase activity that controls internalization of receptor-bound albumin is constitutive or subject to regulation. Currently it is unknown whether the range of extracellular stimuli that stimulate production of PtdIns $(3,4,5) \mathrm{P}_{3}$ in $\mathrm{OK}$ cells also stimulate albumin endocytosis. These studies raise the possibility that regulatory mechanisms of albumin endocytosis may interact with growth and mitogenic pathways in tubular epithelial cells and provide a potential explanation for some of the proposed toxicity of proteinuric states. 


\section{Acknowledgments}

This work was supported by the Medical Research Council of the UK, and The Wellcome Trust. N.J. Brunskill holds a Wellcome Trust Advanced Fellowship.

\section{References}

1. Galaske, R.G., C.A. Baldamus, and H. Stolte. 1978. Plasma protein handling in the rat kidney: micropuncture experiments in the acute heterologous phase of anti-GBM-nephritis. Pflugers Arch. 375:269-277.

2. Landwehr, D.M., J.S. Carvalho, and D.E. Oken. 1976. Micropuncture studies of the filtration and absorption of albumin by nephrotic rats. Kidney Int. 11:9-17.

3. Lewy, J.E., and A. Pesce. 1973. Micropuncture study of albumin transfer in aminonucleoside nephrosis in the rat. Pediatr. Res. 7:553-559.

4. Oken, D.E., and W. Flamenbaum. 1971. Micropuncture studies of proximal tubule albumin concentrations in normal and nephrotic rats. J. Clin. Invest. 50:1498-1505.

5. Clapp, W.L, C.H. Park, K.M. Madsen, and C.C. Tisher. 1988. Axial heterogeneity in the handling of albumin by the rabbit proximal tubule. Lab. Invest. 58:549-558.

6. Wall, D.A., and T. Maack. 1985. Endocytic uptake, transport, and catabolism of proteins by epithelial cells. Am. J. Physiol. 248:C12-C20.

7. Christensen, E.I., and S. Nielsen. 1991. Structural and functional features of protein handling in the kidney proximal tubule. Semin. Nephrol. 11:414-439.

8. Schwegler, J.S., B. Heppelmann, S. Mildenberger, and S. Silbernagl. 1991. Receptor mediated endocytosis of albumin in cultured opossum kidney cells: a model for proximal tubular reabsorption. Pflugers Arch. 418:383-392.

9. Brunskill, N.J., N. Cockcroft, S. Nahorski, and J. Walls. 1996. Albumin endocytosis is regulated by heterotrimeric GTP-binding protein $\mathrm{G}_{\mathrm{i}-3}$ in opossum kidney cells. Am. J. Physiol. 271:F356-F364.

10. Thomas, M.E., and G.F. Schreiner. 1993. Contribution of proteinuria to progressive renal injury: consequences of tubular uptake of fatty acid bearing albumin. Am. J. Nephrol. 13:385-398.

11. Burton, C.J., A. Bevington, K.P.G. Harris, and J. Walls. 1994. The growth of proximal tubular cells in the presence of albumin and proteinuric urine. Exp. Nephrol. 2:345-350.

12. Brunskill, N.J., S. Nahorski, and J. Walls. 1997. Characteristics of albumin binding to opossum kidney cells and identification of potential receptors. Pflugers Arch. 433:497-504.

13. Liscovitch, M., and L.C. Cantley. 1995. Signal transduction and membrane traffic: the PITP/phosphoinositide connection. Cell. 81:659-662.

14. De Camilli, P., S.D. Emr, P.S. McPherson, and P. Novick. 1996. Phosphoinositides as regulators of membrane traffic. Science. 271:1533-1539.

15. Shepherd, P.R., B. Reaves, and H.W. Davidson. 1996. Phosphoinositide 3-kinases and membrane traffic. Trends Cell Biol. 6:92-97.

16. Schu, P.V., K. Takegawa, M.J. Fry, J.H. Stack, M.D. Waterfield, and S.D. Emr. 1993. Phosphatidylinositol 3-kinase encoded by yeast VPS34 gene essential for protein sorting. Science. 260:88-91.

17. Stephens, L., F.T. Cooke, R. Walters, T. Jackson, S. Volinia, I. Gout, M.D. Waterfield, and P.T. Hawkins. 1994. Characterization of a phosphatidylinositol specific phosphoinositide 3-kinase from mammalian cells. Curr. Biol. 4: 203-214.

18. Volinia, S., R. Dhand, B. Vanhaesebroeck, L.K. MacDougall, R. Stein, M.J. Zvelebil, J. Domin, C. Panaretou, and M.D. Waterfield, 1995. A human phosphatidylinositol 3-kinase complex related to yeast $\mathrm{Vps} 34 \mathrm{p}-\mathrm{Vps} 15 \mathrm{p}$ protein sorting system. EMBO (Eur. Med. Biol. Organ.) J. 14:3339-3348.

19. Stephens, L., A. Smrcka, F.T. Cooke, T.R. Jackson, P.C. Sternweis, and P.T. Hawkins. 1994. A novel phosphoinositide 3-kinase activity in myeloid derived cells is activated by G-protein $\beta \gamma$-subunits. Cell. 77:83-93.

20. Stoyanov, B., S. Volinia, T. Hanck, I. Rubio, M. Loubtchenkov, D. Malek, S. Stoyanova, B, Vanhaesebroeck, R. Dhand, B. Nurnberg et al. 1995. Cloning and characterization of a $\mathrm{G}$ protein activated human phosphoinositide 3-kinase. Nature. 269:690-693.

21. Fry, M., and M.D. Waterfield. 1993. Structure and function of phosphatidylinositol 3-kinase: a potential second messenger system involved in growth control. Philos. Trans. R. Soc. Lond. B. Biol. Sci. 340:337-344.

22. Stephens, L.R., T.R. Jackson, and P.T. Hawkins. 1993. Agonist stimulated synthesis of phosphatidylinositol $(3,4,5)$ trisphosphate: a new intracellular signalling system. Biochim. Biophys. Acta. 1179:27-75.

23. Jhun, B.H., D.W. Rose, B.L. Seely, L. Rameh, L. Cantley, A.R. Saltiel, and J.M. Olefsky. 1994. Microinjection of the SH2 domain of the 85-kilodalton subunit of phosphatidylinositol 3-kinase inhibits insulin-induced DNA synthesis and c-fos expression. Mol. Cell Biol. 14:7466-7475.

24. Rodriguez-Viciana, P., P.H. Warne, R. Dhand, B. Vanhaesebroeck, I. Gout, M.J. Fry, M.D. Waterfield, and J. Downward. 1994. Phosphatidylinositol3-OH kinase as a direct target of Ras. Nature. 370:527-532.

25. Hu, Q., A. Klippel, A.J. Muslin, W.J. Fantl, and L.T. Williams. 1995.
Ras-dependent induction of cellular responses by constitutively active phosphatidylinositol-kinase. Science. 268:100-102.

26. Tsakiridis, T., C. Taha, S. Grinstein, and A. Klip. 1996. Insulin activates a p21-activated kinase in muscle cells via phosphatidylinositol 3-kinase. J. Biol. Chem. 271:19664-19667.

27. Hawes, B.E., L.M. Luttrell, T. van Biesen, and R.J. Lefkowitz. 1996 Phosphatidylinositol 3-kinase is an early intermediate in the G $\beta \gamma$-mediated mitogen activated protein kinase signaling pathway. J. Biol. Chem. 271:1213312136.

28. Hara, K., K. Yonezawa, H. Sakaue, A. Ando, K. Kotani, T. Kitamura, Y. Kitamura, H. Ueda, L. Stephens, T.R. Jackson, et al. 1994. Phosphatidylinositol 3-kinase activity is required for insulin-stimulated glucose transport but not for RAS activation in CHO cells. Proc. Natl. Acad. Sci. USA. 91:7415-7419.

29. Katgiri, H., T. Asano, H. Ishihara, K. Inukai, Y. Shibasaki, M. Kikuchi, Y. Yazaki, and Y. Oka. 1996. Overexpression of catalytic subunit $\mathrm{p} 110 \alpha$ of phosphatidylinositol 3-kinase increases glucose transport activity with translocation of glucose transporters in 3T3-L1 adipocytes. J. Biol. Chem. 271:1698716990.

30. Araki, N., M.T. Johnson, and J.A. Swanson. 1996. A role for phosphoinositide 3-kinase in the completion of macropinocytosis and phagocytosis by macrophages. J. Cell Biol. 135:1249-1260.

31. Clague, M.J., C. Thorpe, and A.T. Jones. 1995. Phosphatidylinositol 3-kinase regulation of fluid phase endocytosis. FEBS Lett. 367:272-274.

32. Jones, A.T., and M.J. Clague. 1995. Phosphatidylinositol 3-kinase activity is required for early endosome fusion. Biochem. J. 311:31-34.

33. Nakanishi, S., J.K. Catt, and T. Balla. 1995. A wortmannin sensitive phosphatidyl 4-kinase that regulates hormone sensitive pools of inositol phospholipids. Proc. Natl. Acad. Sci. USA. 92:5317-5321.

34. Hartley, K.O., D. Gell, G.C. Smith, H. Zhang, N. Divecha, M.A. Connelly, A. Admon, S.P. Lees-Miller, C.W. Anderson, and S.P. Jackson. 1995. DNA-dependent protein kinase: a relative of phosphatidylinositol 3-kinase and the ataxia telangectasia gene product. Cell. 82:849-856.

35. Cross, M.J., A. Stewart, M.N. Hodgkin, D.J. Kerr, and M.J.O. Wakelam. 1995. Wortmannin and it's structural analogue demethoxyviridin inhibit stimulated phospholipase A2 activity in Swiss 3T3 cells. Wortmannin is not a specific inhibitor of phosphatidylinositol 3-kinase. J. Biol. Chem. 270: 25352-25355.

36. Batty, I.H., A.N. Carter, R.A.J. Challiss, and J.N. Hawthorne. 1997. Receptor linked phosphoinositide metabolism. In Neurochemistry: A Practical Approach. A.J. Turner and H.S. Bachelard, editors. IRL Press at Oxford University Press, Oxford, U.K. 229-268.

37. Eker, P., P.K. Holm, B. van Deurs, and K. Sandvig. 1994. Selective regulation of apical endocytosis in polarized Madin Darby canine kidney cells by mastoparan and cAMP. J. Biol. Chem. 269:18607-18615.

38. Hansen, S.H., A. Olsson, and J. Casanova. 1995. Wortmannin, an inhibitor of phosphoinositide 3-kinase, inhibits transcytosis in polarized epithelial cells. J. Biol. Chem. 270:28425-28432.

39. Valentich, J.D. 1981. Morphological similarities between the dog kidney cell line MDCK and the mammalian cortical collecting tubule. Ann. NY Acad. Sci. 372:384-405.

40. Koyama, H., C. Goodpasture, M.M. Miller, R.L. Teplitz, and D. Riggs. 1978. Establishment and characterization of a cell line from the American opossum (Didelphys virginiana). In Vitro. 14:239-246.

41. Malstrom, K., G. Strange, and H. Murer. 1987. Identification of proximal tubular transport functions in the established kidney cell line, OK. Biochim. Biophys. Acta. 902:269-277.

42. Vlahos, C., W.F. Matter, K.Y. Hui, and R. Brown. 1994. A specific inhibitor of phosphatidylinositol 3-kinase, 2-(morpholinyl)-8-phenyl-4H-1-benzopyran-4-one (LY294002). J. Biol. Chem. 269:5241-5248.

43. Domin, J., and M.D. Waterfield. 1997. Using structure to define function of phosphoinositide 3-kinase family members. FEBS Lett. 410:91-95.

44. Zoellner, H., M. Hofler, R. Beckmann, P. Hufnagl, E. Vanyek, E. Bielek, J. Wojta, A. Fabry, S. Lockie, and B. Binder. 1996. Serum albumin is a specific inhibitor of apoptosis in human endothelial cells. J. Cell Sci. 109:25712580.

45. Tirrupathi, C., W. Song, M. Bergenfeldt, P. Sass, and A. Malik. 1997. Gp60 activation mediates transcytosis in endothelial cells by tyrosine kinasedependent pathway. J. Biol. Chem. 272:25968-25975.

46. Yao, R., and G.M. Cooper. 1995. Requirement for phosphatidylinositol-3 kinase in the prevention of apoptosis by nerve growth factor. Science. 267: 2003-2006.

47. Holdago-Madruga, M., D.K. Moscatello, D.R. Emlet, R. Dietrich, and A.J. Wong. 1997. Grb2-associated binder-1 mediates phosphatidylinositol 3-kinase activation and the promotion of cell survival by nerve growth factor. Proc. Natl. Acad. Sci. USA. 94:12419-12424.

48. Joly, M., A. Kazlauskas, and S. Corvera. 1995. Phosphatidylinositol 3-kinase activity is required at a postendocytic step in platelet derived growth factor receptor trafficking. J. Biol. Chem. 270:13225-13230.

49. Li, G., C. D'Souza-Schorey, M.A. Barbieri, R.L. Roberts, A. Klippel, L.T. Williams, P.D. Stahl. 1995. Evidence for phosphatidylinositiol 3-kinase as a regulator of endocytosis via activation of Rab 5. Proc. Natl. Acad. Sci. USA. 92: 10207-10211. 
50. Ireton, K., B. Payrastre, H. Chap, W. Ogawa, H. Sakaue, M. Kasuga, and P. Cossart. 1996. A role for phosphoinositide 3-kinase in bacterial invasion. Science. 274:780-782.

51. Reaves, B., N. Bright, B.M. Mullock, and J.P. Luzio. 1996. The effect of wortmannin on the localization of lysosomal type I integral membrane glycoproteins suggests a role for phosphoinositide 3-kinase activity in regulating membrane traffic late in the endocytic pathway. J. Cell Sci. 109:749-762.
52. Toker, A., and L. Cantley. 1997. Signaling through the lipid products of phosphoinositide-3-OH-kinase. Nature. 387:673-676.

53. Gaidarov, I., Q. Chen, J.R. Falck, K.K. Reddy, and J. Keen. 1996. A functional phosphatidylinositol 3,4,5-trisphosphate/phosphoinositide binding domain in the clathrin adaptor AP- $2 \alpha$ subunit. Implications for the endocytic pathway. J. Biol. Chem. 271:20922-20929. 